\title{
Public Innovation Support Index for Impact Assessment in the European Economic Area
}

\author{
Mantas Vilys, Artūras Jakubavičius, Eigirdas Žemaitis
}

\begin{abstract}
A B S T R A C T
Objective: The object of this research is public innovation support in the European Economic Area and its effectiveness assessment. The main aim is to propose a new model for public innovation support effectiveness assessment, adjusted to contemporary needs and based on practice of public innovation support development.

Research Design \& Methods: The methods of comparative, cluster, regression, modelling analysis, multi-criteria evaluation, analogy search, logical abstraction and impact evaluation have been applied for the research presented in this paper.

Findings: The paper conceptualizes a new model for the assessment of public innovation support. It is based on theoretical argumentation and practical verification. Its structure is based on new solutions and quantitative assessment methods.

Implications \& Recommendations: The analysis of the proposed model applicability revealed important patterns for the public innovation support impact assessment. Findings suggest that the increase of public innovation support index is a necessary but insufficient condition for the growth of the countries innovation index. The impact of public innovation support occurs only in the long run, as the delay of the effect exists.
\end{abstract}

Contribution \& Value Added: The proposed system of quantitative and qualitative indicators that characterize any public innovation support system (public innovation support index) enables the creation and implementation of measures devoted to the public innovation support impact improvement at EU and national level. The practical application of the suggested model is significant for the effectiveness improvement of public innovation support at EU institutions.

\begin{tabular}{ll}
\hline Article type: & research paper \\
Keywords: & innovation; public innovation support; impact assessment; index \\
JEL codes: & O38, C43
\end{tabular}

Received: 29 March 2015 Revised: 2 December 2015 Accepted: 14 December 2015

\section{Suggested citation:}

Vilys, M., Jakubavičius, A., \& Žemaitis, E. (2015). Public Innovation Support Index for Impact Assessment in the European Economic Area. Entrepreneurial Business and Economics Review, 3(4), 123138, DOI: http://dx.doi.org/10.15678/EBER.2015.030408 


\section{INTRODUCTION}

The current global economic crisis emphasizes the need for efficient and effective use of public funding for the benefit of public interest. Under such circumstances increased pressure is put on public budgets. According to the EU wide studies the impact of the crisis on innovation expenditures seems to be the greatest in low tech manufacturing sectors and in countries classified as "catching up" by the European Innovation Scoreboard (Pro Inno Europe, 2012). As a direct impact of the economic crisis, the innovation gap in the EU risks to be widened again. The need of new approaches for the assessment of public innovation support is caused by:

- limited understanding on how to assess the relevance of public innovation support schemes and their adjustment to the needs of businesses and public interest (EUFP, 2013; Goel, 2012);

- limited effectiveness of public innovation support (Luke, 2010);

- lack of an indicator systems suitable for the comparative analysis of complex public innovation support systems at national levels and at EU level;

- absence of theoretical background which could justify the creation and development of complex public innovation support systems relevant to the national socio-economic challenges.

By reacting to the all above stated challenges the issues of public innovation support assessment has recently received an increasing attention among scholars and practitioners. However, only with few exceptions, scientific studies have been based on the analysis of particular innovation policies or instruments in limited manner neglecting almost completely the specific policy dilemmas arising from weak and fragmented understanding of support impact.

In developed countries innovation has been the key engine for economic development enabling those countries to reach international competitiveness and high quality of people's life. Additionpally we can observe a trend of shortening the time of diffusion of innovations, which in practice means faster introduction and adaptation of innovative solutions (Kosała \& Wach, 2014). In view of the complex and strategic character of innovation processes and their significance for countries, the intervention of the public sector in the innovation development and promotion process is not only possible, but necessary.

In order to ensure qualitative development of public innovation support systems which are relevant to the needs of business, but also match the public interest, it is very important to understand the synergies of multiple public support actions under holistic innovation paradigm and to suggest novel and comprehensive approaches for national innovation support system assessment (Tan, 2004; Melnikas, 2005). New assessment methods of public innovation support is important for the science of management at the national as well as at supranational level. The assessment of public innovation support effectiveness is an important field for the scientific research due to the following reasons:

- it creates a ground for rationalisation of public innovation support policies;

- it justifies appropriateness of public funds allocated for this support;

- it encourages the improvement of public support, its effectiveness, thus reforming current and introducing new support programmes and measures. 
Therefore, it is very important to explore and suggest new approaches, methods and instruments for the modern public innovation support assessment. This paper discusses conceptual frameworks for assessment of the impact of public innovation support while applying conventional descriptive methods to explore the changes in innovation in the European Economic Area.

The value added of this paper lies in the following areas:

- with the definition of a new research field in the area of public innovation support effectiveness assessment, it can create ground for a better perception of public support impact;

- common for EU and specific to Lithuania patterns of public innovation support development practice were identified which create new opportunities for the improvement of public support effectiveness;

- the proposed system of quantitative indicators enables the creation and implementation of measures devoted to the public innovation support effectiveness improvement at EU and national level;

- suggested model for the assessment of public innovation support is based on theoretical argumentation and practical verification; its structure is based on new solutions and quantitative assessment methods.

\section{LITERATURE REVIEW}

\section{Previous Research of Public Innovation Support Impact Assessment}

The emphasis on public innovation support is caused by the widespread conviction that innovation contribute significantly to GDP growth and to solving important socioeconomic challenges. The impact of public innovation support on the development of innovation is not scientifically and practically explored enough. Some scientific research has been made to identify the effects of public innovation support measures nevertheless this research remains fragmented. By referring to the current state of art in supporting innovation by different public actions the main research areas are as follows:

- organisational and institutional forms for public innovation support (Ertmer \& Ottenbreit-Leftwich, 2010; EUFP, 2013; Goel, 2012; Luke, 2010; Minogue, 2005; Fung \& Wright, 2001; Gavin \& Muers, 2002; MacPherson, 2001; Straits, 2002; Sherwood, 2002);

- the role and models of public innovation support in fostering innovation in business (Naštase, 2013; Noor, 2010; Barrett \& Hill, 1984; Braczyk, Cooke, \& Heidenreich, 1998; Miles, 2004; Earl, 2004; Tan, 2004; Melnikas, 2005);

- public sector as a main developer of innovations. The paradigm of full governmental involvement for the generation and dissemination of innovation (Pacharapha \& Ractham, 2012; Rutkauskas \& Račinskaja, 2013; Bhatta, 2003; Cainelli, Evangelista, \& Savona, 2004);

- provision of innovation support services in line with other public measures. In this case the main scope of the research is to explore key elements for the efficient delivery of public support (Santos Silva, 2013; Sullivan \& Marvel, 2011; Gallouj, 2006; Tekes, 2007).

By summarising different scientific suggestions (Antonelli, 2009; Cassiman \& Veugelers, 2002; Miravete \& Pern, 2000; Beerepoot, 2007; Blake \& Hanson, 2005; Blindenbach, 
2006) public innovation support can be defined as an activity which is planned, organized, implemented and controlled by public or private institutions under the public interest with the aim to foster innovation in all possible areas. By following this approach government, industry and universities can work in partnership in order to take all benefits of public support measures during the current global economic crisis. Adequate assessment of public innovation support can guarantee further development of the economy in a manner that is relevant to the needs of business, but also matching the public interest.

In recent years, the assessment of impact of public innovation support took a substantial evolution. According to the neoclassical tradition, the discussion on rationales for public intervention is robustly linked to the notion of optimality. According to the neoclassical theory classics (Vargas-Hernandez, 2011; Varghese, 2013; Bator, 1958; Medema, 2004; Mankiw et al., 2002; Mohnen et al., 2004) public sector should intervene to solve those market failures that prevent achieving the optimal development of innovation. As opposed to the neoclassical theories, the notion of optimality is considered to be irrelevant by the systems of innovation approach. It focuses on the evolutionary nature of innovation processes that are path dependent over time and it is not clear which path will be taken (Edquist \& Chaminade, 2006). Therefore in systems that never achieve equilibrium, the notion of optimality is irrelevant. Under this paradigm the rationale for public innovation support is based on identification, analysis and elimination of systemic problems (Bastalich, 2010; Boehm \& Fredericks, 2010; Camic \& Grossm, 2012; Chaminade \& Edquist, 2006; Hassink \& Dong-Ho, 2005; Lundvall, 2007; Edquist, 2001; Heidenreich, 2004; Juma, 2005; Nelson, 2002). After an in-depth analysis of different theoretical approaches the concept of holistic innovation system was selected as the background to design a new proposition of an assessment model of public innovation support. Table 1 depicts the main methods used for the assessment of public innovation support and the main results from selected recent related studies.

Table 1. Recent studies for the assessment of the public innovation support impact

\begin{tabular}{|l|l|l|}
\hline Year & Authors & \multicolumn{1}{c|}{ Results } \\
\hline 2012 & Almus & $\begin{array}{l}\text { Companies that participated in public R\&D schemes increased R\&D-invest- } \\
\text { ments with an amount corresponding to 4\% of their turnover. }\end{array}$ \\
\hline 2013 & Duguet & R\&D subsidies add to the private R\&D. \\
\hline 2013 & Wong & $\begin{array}{l}\text { Public subsidies contribute to private funding of R\&D. Regression methods } \\
\text { suggest that one additional dollar in R\&D subsidy would increase private } \\
\text { R\&D spending by 0.41 USD. }\end{array}$ \\
\hline 2014 & $\begin{array}{l}\text { Schibany } \\
\text { et al. }\end{array}$ & $\begin{array}{l}\text { Firms with fewer than 10 employees and firms with more than 250 employ- } \\
\text { ees exhibit the highest leverage from public innovation support. }\end{array}$ \\
\hline
\end{tabular}

Source: own elaboration based on (Almus, 2012; Duguet, 2013; Wong, 2013; Schibany et al., 2014).

Taking into account the holistic innovation system approach and the scientific studies, which were made to explore the impact of public innovation support, further analysis focused on identification and classification of various public support additionality concepts and their sub-dimensions. Additionally quantitative parameters as well as descriptive methods were used to explore how companies rate and rank the merits of public innovation support. 
In the last years, a growing number of countries have adopted the innovation system approach to create and disseminate public innovation support systems. Nevertheless this process requires an extensive analysis that could be supported by new models for the assessment of such systems. For this purpose further research priorities were identified:

- research in which the possibility to apply neoclassical and systems of innovation theoretical approach to the assessment of public innovation support are evaluated;

- research in which classification of various public support impact concepts and their subdimensions are explored;

- research during which the models for creation, dissemination and evaluation of public innovation support are elaborated.

Taking into account the recent studies on assessment of public innovation support impact, a model for effectiveness assessment of public innovation support has been suggested by hereby authors. By following the proposed assessment principles new public innovation support effects has been identified. The suggested model for the assessment of public innovation support in the European Economic Area is depicted below (Figure 1).

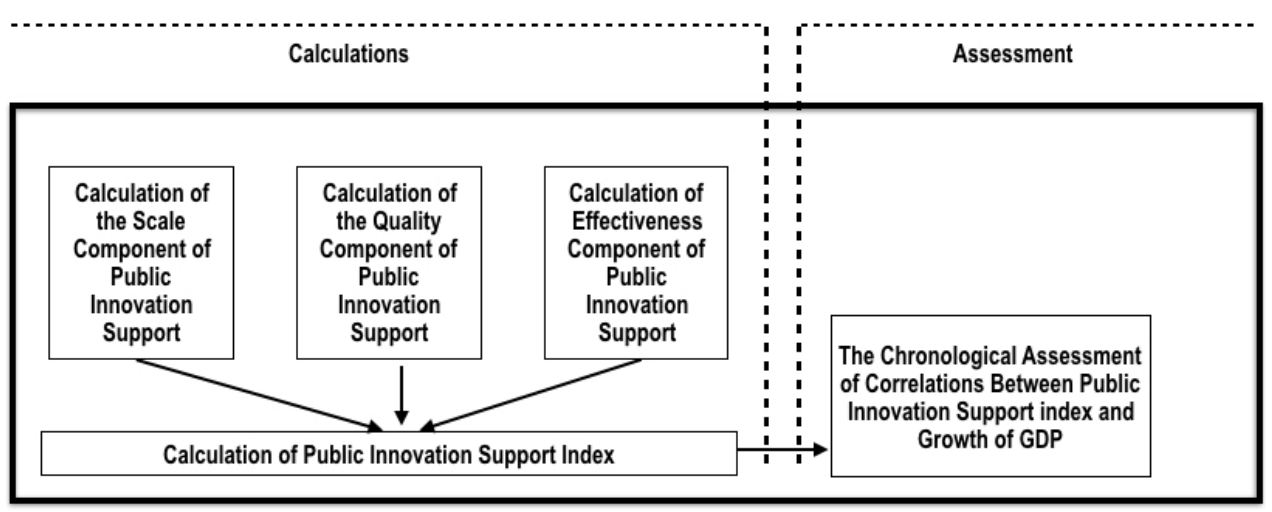

Figure 1. The model for the assessment of public innovation support

Source: own elaboration based on (Almus, 2012; Duguet, 2013; Wong, 2013).

The proposed assessment of public innovation support impact in the European Economic Area is based on public innovation support index and chronological assessment of correlations between public innovation support index and growth rate of GDP in particular country.

\section{Public Innovation Support Index Calculation}

By summarising analysed scientific literature, it can be stated that an accurate assessment is necessary for the better design and development of public innovation support systems. By applying common principles for assessment of the existing national support schemes we will be able to compare characteristics of available international experience in designing and development of public innovation support systems. In this context, it is important to propose a new index that can help characterize every public innovation support system in every country. In the context of social sciences index is the relative indicator of the phenomenon in question that characterizes it according to the selected reference system 
(Diewert, 2009). For example - consumer price index is a set of prices (with a particular weigh) that is expressed in a relative, synthetic and numeric form. In the figure below the summary of different indexes that can be used for public innovation support systems analysis is presented (Figure 2). In this case, the innovation index - the synthetic indicator that not only reflects innovation activities and related public support but also ranks countries/economies in terms of their environment to innovation and their innovation outputs.

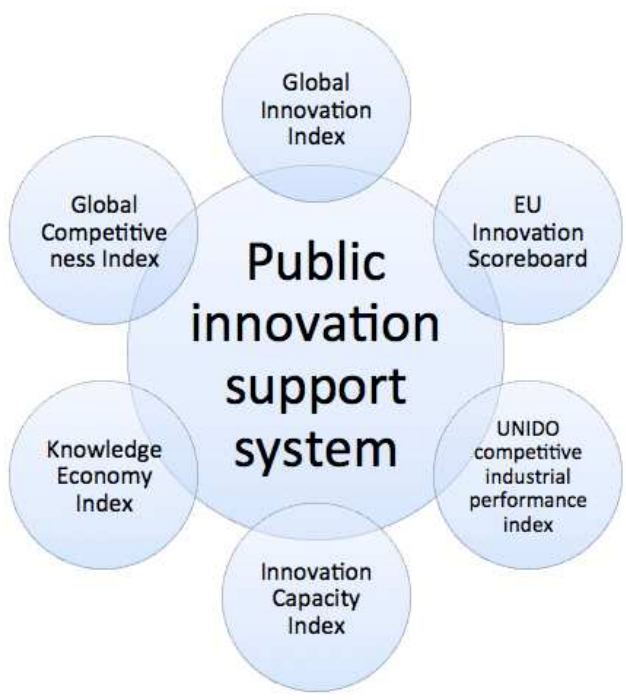

Figure 2. Indexes applicable for the comparative analysis of public innovation support systems Source: own elaboration based on (World Bank, 2011; UNIDO, 2011; Porter \& Stern, 2001; UNCTAD, 2011; Pro Inno Europe, 2012).

Table 1. Indexes that could be used for characterization of public innovation support system

\begin{tabular}{|l|c|c|c|c|c|c|}
\hline \multicolumn{1}{|c|}{ Dimension of the innovation system } & CIPI & GII & IS & GCI & KEI & ICI \\
\hline Investment in Innovation Activities & $\mathrm{x}$ & $\mathrm{x}$ & $\mathrm{x}$ & $\mathrm{x}$ & $\mathrm{x}$ & $\mathrm{x}$ \\
\hline Output of Innovation Activities & $\mathrm{x}$ & $\mathrm{x}$ & $\mathrm{x}$ & $\mathrm{x}$ & & \\
\hline Impact of Innovation Activities & & $\mathrm{x}$ & & $\mathrm{x}$ & $\mathrm{x}$ & $\mathrm{x}$ \\
\hline Scale of Public Innovation Support & & & & & & $\mathrm{x}$ \\
\hline Quality of Public Innovation Support & & & & & $\mathrm{x}$ & $\mathrm{x}$ \\
\hline Impact of Public Innovation Support & 8 & 81 & 24 & 11 & 12 & 61 \\
\hline Number of indicators in the index & & & \\
\hline \begin{tabular}{l} 
Acronyms: CIPI- Competitive Industrial Performance Index; GII - Global Innovation Index; \\
IS - EU Innovation Scoreboard; GCI - Global Competitiveness Index; \\
KEI - Knowledge Economy Index; ICI - Innovation Capacity Index. \\
\hline
\end{tabular}
\end{tabular}

Source: own elaboration based on (World Bank, 2011; Desai, 2002; UNIDO, 2011; Porter \& Stern, 2001; UNCTAD, 2011; Pro Inno Europe, 2012; Claros \& Yasmina, 2009).

Through an in-depth comparative analysis of all suggested indexes that could be used to characterize the public innovation support system, it was possible to identify the limitations that are vitally important for further development of public innovation support systems. The results of this analysis are presented in the Table 1. 
With respects to conclusions of the comparative index analysis it is necessary to create a new, cumulative index that can reflect all important characteristics of existing public innovation support systems. The proposed public innovation support index should have a composite structure of qualitative and quantitative indicators that reflect three most important dimensions of public innovation support - scale, quality and impact. The proposed set of indicators is presented in the Table 2.

Table 2. Proposed structure of the public innovation support index

\begin{tabular}{|c|c|c|}
\hline $\begin{array}{l}\text { Component } \\
\text { of the index }\end{array}$ & Indicator & Source \\
\hline \multirow{5}{*}{ 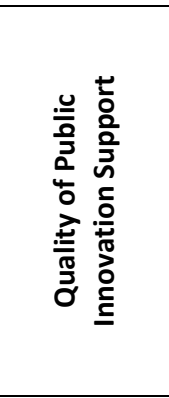 } & $\begin{array}{l}\text { Government expenditure on education } \\
\text { (\% of GDP) }\end{array}$ & $\begin{array}{l}\text { UNESCO Institute for Statistics, UIS } \\
\text { online database }\end{array}$ \\
\hline & $\begin{array}{l}\text { R\&D expenditure in the } \\
\text { public sector (\% of GDP) }\end{array}$ & Eurostat \\
\hline & State aid for R\&D (\% of GDP) & DG Competition, Eurostat \\
\hline & $\begin{array}{l}\text { Researchers in R\&D (per million peo- } \\
\text { ple) }\end{array}$ & $\begin{array}{l}\text { World Development Indicators, World } \\
\text { Bank }\end{array}$ \\
\hline & $\begin{array}{l}\text { New doctorate graduates } \\
\text { (ISCED 6) per } 1000 \\
\text { population aged } 25-34\end{array}$ & Eurostat \\
\hline \multirow{14}{*}{ 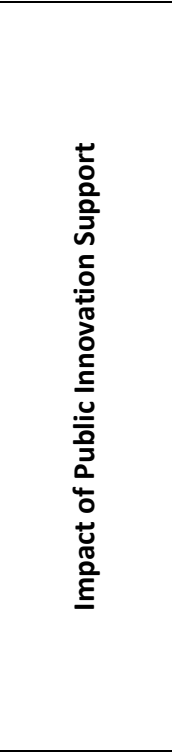 } & $\begin{array}{l}\text { Quality of scientific research institu- } \\
\text { tions }\end{array}$ & World Economic Forum \\
\hline & $\begin{array}{l}\text { Quality of scientific research institu- } \\
\text { tions }\end{array}$ & World Economic Forum \\
\hline & Availability of scientists and engineers & World Economic Forum \\
\hline & Extent of staff training & World Economic Forum \\
\hline & Quality of the educational system & World Economic Forum \\
\hline & Public policy stability & World Bank, Governance Indicators \\
\hline & Government effectiveness index & World Bank, Governance Indicators \\
\hline & \begin{tabular}{|l|} 
Effectiveness of legal system \\
\end{tabular} & World Economic Forum \\
\hline & Regulatory quality index & World Bank, Governance Indicators \\
\hline & Rule of law index & World Economic Forum \\
\hline & Regulatory quality & $\begin{array}{l}\text { World Bank, World Governance Indica- } \\
\text { tors }\end{array}$ \\
\hline & Ease of starting a business & $\begin{array}{l}\text { World Bank, Ease of Doing Business In- } \\
\text { dex } 2014\end{array}$ \\
\hline & Press freedom index & $\begin{array}{l}\text { Reporters Without Borders, Press Free- } \\
\text { dom Index } 2013\end{array}$ \\
\hline & Quality of IPR system & World Economic Forum \\
\hline
\end{tabular}

Source: own elaboration based on (World Bank, 2011; UNIDO, 2011; UNCTAD, 2011; Pro Inno Europe, 2012).

\section{MATERIAL AND METHODS}

Since the data used for calculation of proposed innovation support index is non-homogenous it should be normalized by applying the formula below.

$$
R_{n}=\frac{R_{i}-R_{\min }}{R_{\max }-R_{\min }}
$$


where:

$R_{n} \quad$ - normalized value of particular indicator;

$R_{j} \quad$ - analysed value of particular indicator in the $i$ country;

$R_{\text {min }}$ - lowest value of particular indicator;

$R_{\max }$ - highest value of particular indicator.

Data normalization method for public innovation support index values is based on prior suggestions made by authors (Smith \& Glass, 1987; Stake, 1995; Thomas \& Nelson, 1996) and takes into account the both the maximum and the minimum value.

It is possible to attribute a specific significance for every component of the proposed public innovation support index by applying the formula below:

$$
I_{i}=\frac{I_{m i} \omega_{1}+I_{k i} \omega_{2}+I_{v i} \omega_{3}}{\omega_{1}+\omega_{2}+\omega_{3}}
$$

where:

$$
\begin{array}{ll}
I_{m i} & \text { - indicator for the scale component of public innovation support index in } \\
& \text { the country referred as } i \text {; } \\
I_{k i} & \text { - indicator for the quality component of public innovation support index in } \\
& \text { the country referred as } i ; \\
I_{v i} & \text { - indicator for the impact component of public innovation support index in } \\
& \text { the country referred as } i ; \\
\omega & \text { - significance of the particular component in question. }
\end{array}
$$

It should be considered that all public innovation support system components may be equally important for countries in the European Economic Area, especially when taking into account different social, economic, and cultural context. To enable comparability, it is therefore suggested, to consider all components of the index as equally important (for example, as it is a case in calculation of global Entrepreneurship and Development Index).

Such assessment could be accomplished by applying regression analysis, where frequency tables of positive and negative "events" are generated. The "event" in this context is understood as a year to year increase of country's GDP growth rate in the relation to the increased public innovation support index. It is also important to consider the fact that the impact of public innovation support that results in increase of GDP growth rate could happen with some delay (Drennan \& McConnell, 2007; Hood \& Miller, 2009; Brown, 2010). Nevertheless the precise quantitative expression of the delay in question still remains unsolved. The approach suggested for solving this challenge is based on application of proposed public innovation index in regression analysis with the GDP growth rate. It is possible to calculate the delay of public innovation support by performing a series of regression analysis with variable time shift (expressed in years) values.

The chronological assessment of interrelations between public innovation support index and the GDP growth rate for a particular country can be performed by following main methodological steps as described below.

At first, the sequence of yearly innovation support index values is created for as long period as possible. In order to achieve statistical significance of the analysis this period should be at least 10 years. The sequence of innovation support indexes is expressed in the following way:

$$
I=\left\{I_{k} ; I_{k+1} ; \ldots ; I_{k+n}\right\}
$$


where:

$I_{k} \quad$ - public innovation support index of the country in the year $k$;

$n \quad$ - the number of years used in the analysis.

Based on the sequence that is expressed by formula no. 3 the sequence of yearly $\Delta$ is calculated:

$$
\begin{gathered}
\Delta I=\left\{\Delta I_{k+1} ; \Delta I_{k+2} ; \ldots ; \Delta I_{k+n}\right\} \\
\Delta I_{k+1}=I_{k+1}-I_{k}
\end{gathered}
$$

where:

$\Delta I_{k} \quad$ - the change of public innovation support index of the country in the year $k$.

By following the same principles it is important to compose the sequences of changes in GDP growth rates in the following manner:

$$
\Delta G D P_{g}=\left\{\Delta G D P_{g(k+1)} ; \Delta G D P_{g(k+2)} ; \ldots ; \Delta G D P_{g(k+n)}\right\}
$$

where:

$\triangle G D P_{g k} \quad$ - the change of GDP growth rate of the country in the year $k$.

By linking up the sequences expressed in the formula 4, 6 it is possible to compose the frequency table for the regression analysis as it is presented in the table 3.

\begin{tabular}{|c|c|c|c|}
\hline$\triangle B V P_{g}$ & $\Delta B V P_{g}>0$ & $\Delta B V P_{g}=0$ & $\triangle B V P_{g}>0$ \\
\hline$\Delta I>0$ & $n_{11}$ & $n_{12}$ & $n_{13}$ \\
\hline$\Delta l=0$ & $n_{21}$ & $n_{22}$ & $n_{23}$ \\
\hline$\Delta I<0$ & $n_{31}$ & $n_{32}$ & $n_{33}$ \\
\hline
\end{tabular}

Table 3. Frequency table for the expression of dependence of public innovation support index, GDP growth rate

Source: own calculations based on data from the Eurostat.

In this case, the frequency expressed as $n_{11}$ shows the number of cases of positive change in value of public innovation support index that resulted in positive GDP growth rate in the same $k$ year. Further on, the regression analysis is performed and particular factors of regression equations are calculated. In the same manner it is possible to compose the frequency tables where the change of GDP growth rate of the country in the year $k$ is compared not to the same year value change of public innovation support index but to the value change that happened earlier (for instance in the year $k-1, k-2, k-3 . .$. ). By doing so we are able to express and calculate the precise delay of public innovation support impact to the GDP growth rate in particular country.

\section{RESULTS AND DISCUSSION}

\section{Chronological Assessment of Interrelations between Public Innovation Support Index and GDP Growth Rate in the European Economic Area}

In this section the results of verification of the proposed model for the public innovation support characterization as well as for impact assessment is presented. The following 
study was performed with data that covers the last 15 years of public innovation support efforts by all countries in the European Economic Area in the period 1997-2012 and that was linked to the GDP growth rate accordingly following the methodological suggestions that were presented in the paragraph above. Table 4 presents the results of calculation of public innovation support index in the European Economic Area with the data for 2012.

Table 4. Public innovation support index in the European Economic Area in 2012

\begin{tabular}{|c|l|c|c|c|c|}
\hline No. & Country & $\begin{array}{c}\text { Impact of Public In- } \\
\text { novation Support }\end{array}$ & $\begin{array}{c}\text { Scale of Public } \\
\text { Innovation } \\
\text { Support }\end{array}$ & $\begin{array}{c}\text { Quality of Public In- } \\
\text { novation Support }\end{array}$ & $\begin{array}{c}\text { Public Innovation } \\
\text { Support Index }\end{array}$ \\
\hline 1 & Finland & 6.23 & 6.07 & 6.37 & 6.22 \\
\hline 2 & Sweden & 6.26 & 5.59 & 6.17 & 6.01 \\
\hline 3 & Denmark & 6.25 & 5.41 & 6.18 & 5.95 \\
\hline 4 & Iceland & 5.60 & 5.51 & 5.72 & 5.61 \\
\hline 5 & Norway & 5.93 & 4.75 & 5.31 & 5.33 \\
\hline 6 & Netherlands & 5.68 & 4.46 & 5.67 & 5.27 \\
\hline 7 & Ireland & 5.45 & 4.37 & 5.48 & 5.10 \\
\hline 8 & Belgium & 4.74 & 4.38 & 5.92 & 5.01 \\
\hline 9 & Austria & 5.59 & 4.26 & 4.72 & 4.86 \\
\hline 10 & Germany & 5.22 & 4.21 & 5.00 & 4.81 \\
\hline 11 & France & 4.41 & 4.57 & 5.46 & 4.81 \\
\hline 12 & Great Britain & 5.16 & 4.11 & 5.07 & 4.78 \\
\hline 13 & Luxembourg & 5.91 & 3.19 & 3.40 & 4.17 \\
\hline 14 & Cyprus & 4.89 & 3.04 & 4.25 & 4.06 \\
\hline 15 & Czech Rep. & 3.71 & 3.93 & 4.49 & 4.04 \\
\hline 16 & Estonia & 5.11 & 3.16 & 3.69 & 3.99 \\
\hline 17 & Liechtenstein & 5.73 & 2.84 & 3.22 & 3.93 \\
\hline 18 & Slovenia & 4.06 & 3.98 & 3.73 & 3.92 \\
\hline 19 & Malta & 4.93 & 2.48 & 3.07 & 3.50 \\
\hline 20 & Portugal & 3.87 & 2.84 & 3.11 & 3.28 \\
\hline 21 & Spain & 2.86 & 3.40 & 3.50 & 3.25 \\
\hline 22 & Hungary & 3.57 & 2.99 & 2.86 & 3.14 \\
\hline 23 & Lithuania & 3.62 & 2.63 & 2.52 & 2.92 \\
\hline 24 & Poland & 2.75 & 2.73 & 2.99 & 2.82 \\
\hline 25 & Latvia & 3.40 & 2.35 & 2.16 & 2.37 \\
\hline 26 & Greece & 2.91 & 2.75 & 2.18 & 1.72 \\
\hline 27 & Slovakia & 3.34 & 2.41 & 2.97 & \\
\hline 28 & Romania & 2.48 & 2.41 & 2.11 & 2.08 \\
\hline 29 & Italy & 2.41 & 2.41 & 1.35 & \\
\hline 30 & Bulgaria & 1.69 & 2.12 & & \\
\hline 504 & & & \\
\hline
\end{tabular}

Source: own calculations based on data from the Eurostat 2012.

Summarising the data that is depicted in Table 4 all the countries in the European Economic Area can by grouped according to the development level of public innovation support system that in this case is expressed by the value of the proposed public innovation support index: 
- Leaders in public innovation support. In this list - first ten countries with the most developed system of public innovation support: Finland, Sweden, Denmark, Iceland, Norway, Netherlands, Ireland, Belgium, Austria and Germany. This group includes counties in which the public innovation support is developed in average more than $20 \%$ above the EU average.

- The second group of public innovation support followers includes countries with a performance close to that of the EU average i.e. less than $20 \%$ above, or more than $80 \%$ of the EU average (Great Britain, Czech Republic, Estonia, Slovenia etc.).

- The last catching-up group includes countries that show public innovation support performance level well below that of the EU average, i.e. less than $60 \%$ of the EU average. This group includes Bulgaria, Latvia, and Romania.

By following same procedure, the public innovation support index values were calculated for the period 1997-2012 for all countries in the European Economic Area and then linked to the GDP growth rate accordingly. The results of the regression analysis suggest that there is no statistically significant links between the changes in public innovation support (expressed by proposed index) and country's GDP growth rate. In order to confirm the hypothesis that impact of public innovation support occurs with some delay the logit regression was performed repeatedly by shifting the data by one, two, three or more years. The hypothesis was confirmed when some statistically significant links between the public innovation support index values and GDP growth after 2 or more years. The findings of the research shows that the following delay could be expected to the GDP growth while improving the countries public innovation support system:

- expected public innovation support impact delay in the case of Ireland, Lithuania, Cyprus, Greece -3 years;

- expected public innovation support impact delay in the case of Germany, the Netherlands - 4 years;

- expected public innovation support impact delay in the case of Hungary, Ro-mania - 2 years.

The empirical research results confirm the applicability of the proposed model for the characterization of public innovation support systems in the European Economic Area and its applicability for impact assessment. Proposed methodology for the impact assessment can be applied for a further development of public innovation support systems - e.g. if the index of public innovation support is less than 3 then the scale component of public innovation support should be developed, and if the index of public innovation support is above 3 , then the quality component of public innovation support should be developed.

\section{CONCLUSIONS}

Generation and development of innovations are extremely important for modern societies facing social and economic challenges. Innovations enable international competitiveness and sustainable technological, political, economic and social growth of countries. The following patterns for the justification of public innovation support effectiveness assessment could be identified: 
- innovation is related to risk and changes which result in high technical, technological, process and market uncertainty;

- effective public innovation support is able to reduce the risk of innovation and enhances the scale and performance of innovation in business;

- the diversity of support measures is caused by high investment to the development of public innovation support systems, therefore the assessment of interdependent impacts is very complicated.

Despite of the fact that a wide range of research and theoretical studies have been made on the subject of innovation, further exploration of public innovation support is needed due to a lack of its efficiency and limited opportunities to assess its progress.

The comparative analysis of innovation and public innovation support theoretical frameworks and models reveal that in majority cases the challenges of support effectiveness are solved according to the neoclassical and evolutional approaches. This limits our understanding of how different public innovation support measures interact and how the support effects innovation in business. Therefore in order to increase the effectiveness of public support it is very important to follow these directions for scientific research: perform complex analysis of public innovation support systems; create and apply in practice methods for assessment and interpretation of the support impact.

Taking into considerations the diversity of public innovation support measures, the effectiveness assessment should be based on holistic innovation paradigm. By following it, public innovation support effectiveness assessment could be performed with the help of the proposed public innovation support index.

The empirical study where application of proposed model was performed revealed the important patterns for the public innovation support impact assessment.

The increase of public innovation support index is a necessary but insufficient condition for the growth of the countries innovation index. In order to successfully develop public innovation support it is important to focus on effectiveness and quality parameters and not on the scale.

The impact of public innovation support occurs only in the long run, the delay of the effect exists. The study revealed that the public innovation support impact to the countries innovativeness will occur with a 3 years delay (a case of Lithuania and some other EU countries).

The proposed index and approach for the impact assessment could be used in the development and implementation of innovation policies in order to assess the impact of public innovation support at both national and EU level. The application of the model is beneficial for: increase of efficiency of innovation support; increase of long term countries competitiveness; exploration of direct and indirect effects of public innovation support; international comparisons of public support systems according to its effectiveness.

\section{REFERENCES}

Almus, M., \& Czarnitzki, D. (2011). The Effects of Public R\&D Subsidies on Firms' Innovation Activities: The Case of Eastern Germany. Manheim: ZEW.

Antonelli, C. (2009). The economics of innovation: from the classical legacies to the economics of complexity. Economics of Innovation and New Technology, 18(7), 611-646. doi: $10.1080 / 10438590802564543$ 
Barrett, S., \& Hill, M. (1984). Policy, Bargaining and Structure in Implementation Theory: Towards an Integrated Perspective. Policy and Politics, 12(3), 219-240.

Bastalich, W. (2010). Knowledge economy and research innovation. Studies in Higher Education, 35(7), 845-857. doi: 10.1080/03075070903406533

Bator, F. (1958). The Anatomy of Market Failure. Quarterly Journal of Economics, 782(3), 351-379.

Beerepoot, M. (2007). Public Energy Performance Policy and the Effect of Diffusion of Solar Thermal Systems in Buildings: a Dutch Experience. Renewable Energy, 32, 1882-1897.

Bhatta, G. (2003). Don't Just do Something, Stand There. Revisiting the Issue of Risks in Innovation in the Public Sector. The Innovation Journal: A Special Issue on Innovation in Governance, 8(2), 40-55.

Blake, M., \& Hanson, S. (2005). Rethinking Innovation: Context and Gender. Environment and Planning, 37, 681-701.

Blindenbach, F. (2006). Innovation in Project-based Firms: the Context Dependency of Success Factors. Research Policy, 35, 545-561.

Boehm, G., \& Fredericks, L.J. (2010). Strategic innovation management in global industry networks: The TFT LCD Industry. Asian Journal of Business Management, 2(4), 110-120.

Braczyk, H., Cooke, P., \& Heidenreich, M. (1998). Regional Innovation Systems. London: UCL Press Limited.

Brown, L. (2010). Balancing Risk and Innovation to Improve Social Work Practice. British Journal of Social Work, 40(4), 1211-1228.

Cainelli, G., Evangelista, R., \& Savona, M. (2004). The Impact of Innovation on Economic Performance in Services. The Service Industry Journal, 24(1), 66-81.

Camic, Ch., Grossm, N., \& Lamont, M. (2012). Social Knowledge in the Making. Chicago: University of Chicago Press.

Cassiman, B., \& Veugelers, R. (2002). Complementarity in the Innovation Strategy: Internal R\&D, External Technology Acquisition, and Cooperation in R\&D. London: Mimeo.

Chaminade, C., \& Edquist, C. (2006). From Theory to Practice. The Use of the Systems of Innovation Approach in Innovation Policy. Oxford: Oxford University Press.

Claros, L., \& Yasmina, M. (2009). The Innovation Capacity Index: Factors, Policies, and Institutions Driving Country Innovation. Innovation for Development Report 2009-2010. London: Palgrave Macmillan.

Desai, P. (2002). Knowledge Management Research Report. Oxford: NCC, Blackwell.

Diewert, W. E. (2009). Dictionary of Economics. Index Numbers. London: The New Palgrave.

Drennan, L., \& McConnell, A. (2007). Risk and Crisis Management in the Public Sector. London: Routledge.

Duguet, E. (2013). Appropriation Strategy and the Motivations to Use the Patent System: An Econometric Analysis at the Firm Level. Annales d'Economie et de Statistiques, 49(2), 289-328.

Earl, L. (2004). A Historical Comparison of Technological Change, 1998-2000 and 2000-2002, in the Private and Public Sectors. Ottawa: Statistics Canada.

Edquist, C., \& Chaminade, L. (2006). Innovation Policy in the Systems of Innovation Approach: Some Basic Principles. In Knowledge, Complexity and Innovation Systems. Vienna: Springer.

Edquist, Ch. (2001). Innovation Policy in the Systems of Innovation Approach: Some Basic Principles. In Knowledge, Complexity and Innovation Systems. Vienna: Springer. 
Ertmer, P.A., \& Ottenbreit-Leftwich, A.T. (2010). Teacher technology change: how knowledge, confidence, beliefs and culture intersect. Journal of Research on Technology in Education, 42(3), 255-284.

EUFP. (2013). EU Future Program 2014-2020. Retrieved on November 12, 2014, from http://ec.europa.eu/citizenship/about-the-europe-for-citizens-programme/future-programme-20142020/index_en.htm

Fung, A., \& Wright, E. (2001). Deepening Democracy: Innovations in Empowered Participatory Governance. Politics and Society, 29(1), 5-42.

Gallouj, F. (2006). Towards a Theory of Innovation in Services. University of Science and Technology of Lille. Science and Public Policy, 4(13), 11-45.

Gavin, K., \& Muers, S. (2002). Creating Public Value: An Analytical Framework for Public Service Reform. London: Pinter.

Goel, S., Dwivedi, R., \& Sherry, A. M. (2012). Critical factors for successful implementation of E-governance programs: a case study of HUDA. Global Journal of Flexible Systems Management, 13(4), 233-244. doi: 10.1007/s40171-013-0021-1

Hassink, R., \& Dong-Ho S. (2005). The Restructuring of Old Industrial Areas in Europe and Asia. Environment and Planning, 37, 571-580.

Heidenreich, M. (2004). The Dilemmas of Regional Innovation Systems. London: Routledge.

Hood, C., \& Miller, P. (2009). Risk and Public Services. Oxford: ESRC.

Juma, C., \& Yee-Cheong, L. (2005). UN Millennium Project. Innovation: Applying Knowledge in Development. London: Sterling.

Kosała, M., \& Wach, K. (2014). Linking regional knowledge laboratory and growth of SMEs - empirical investigation in southern region of Poland. Prace Komisji Geografii Przemysłu Polskiego Towarzystwa Geograficznego, 26, 113-131.

Luke, B., Verreynne, M. L., \& Kearins, K. (2010). Innovative and entrepreneurial activity in the public sector: The changing face of public sector institutions. Innovation: Management, Policy \& Practice, 12, 138-153. doi: 10.5172/impp.12.2.138

Lundvall, B. A. (2007). National Innovation System: Analytical Focusing Device and Policy Learning Tool. Ostersund: Swedish Institute for Growth Policy Studies.

MacPherson, M. (2001). Performance Excellence Principles - Drivers of Innovation in Public Sector Organisations. Paper presented at the National Conference of the New Zealand, Organ.

Mankiw, G., Kneebone, R., McKenzie, K., \& Row, N. (2002). Principles of Microeconomics: Second Canadian Edition. United States: Thomson-Nelson.

Medema, S. (2004). Public Choice and Deviance. US: An Elgar Reference Collection.

Melnikas, B. (2005). Creation of Knowledge-based Economy in the European Union: the Main Typicalities and New Ideas of Clusterization. Journal of Business Economics and Management, 6(2), 87-100.

Miles, I. (2004). Innovation in Public Services. Presentation at PRIME Conference. Manchester.

Minogue, M. (2005). Apples and Oranges - Comparing International Experiences in Regulatory Reform. Occasional Lecture 13. Bath: Centre for the Study of Regulated Industries.

Miravete, E., \& Pern, J. (2000). Innovation Complementarities and Scale of Production. London: Mimeo.

Mohnen, P., Mairesse, J., \& Dagenais, M. (2004). Innovativeness: a Comparison Across Seven European Countries. Economics of Innovation and New Technology, 13(1-2), 23-35. 
Naštase, G. I. (2013). Innovative models of increasing competition and competitiveness in science. Journal of Knowledge Management, Economics and Information Technology, 2, 233-240.

Nelson, R. (2002). Technology, Institutions, and Innovation Systems. Research Policy, 31, 265-272.

Noor Al-Jedaiah, M. (2010). The impact of information technology (IT) on decision-making process in the public sector. Interdisciplinary Journal of Contemporary Research in Business, 2(5), $320-$ 329.

Pacharapha, T., \& Ractham, V. V. (2012). Knowledge acquisition: the roles of perceived value of knowledge content and source. Journal of Knowledge Management, 16(5), 724-739. doi: $10.1108 / 13673271211262772$

Porter, M. E., \& Stern, S. (2001). National Innovative Capacity. The Global Competitiveness Report 2001-2002. New York: Oxford University Press.

Pro Inno Europe (2012). European Innovation Scoreboard 2012: Comparative Analysis of Innovation Performance. Luxembourg: Office for Official Publications.

Rutkauskas, A. V., \& Racinskaja, I. (2013). Integrated intelligence and knowledge, innovation and technology management, nurturing country universal sustainable development, in 2nd international scientific conference "Problems of modern economy: global, national and regional context", May 23-24, Grodno, Belarus. Grodno: Yanka Kupala State University of Grodno, 1-6.

Santos Silva, L. C., \& Kovaleski, J. L., Gaia, S., Garcia, M., \& Junior, A. (2013). Technology transfer and knowledge management in technological innovation center: a case study in Brazil. Journal of Management and Strategy, 4(2), 78-87. doi: 10.5430/jms.v4n2p78

Schibany, A., Gerhard, S., Gretzmacher, N., Falk, M., Falk, R., Knoll, N., Schwarz, G., \& Wörter, M. (2014). Evaluation FFF - Impact Analysis. InTeReg Research Report Series, 22, 258-299.

Sherwood, D. (2002). Creating an Innovative Culture. UK: Capstone Publishing.

Smith, M., \& Glass, G. (1987). Research and Evaluation in Education and the Social Sciences. New Jersey.

Stake, R. (1995). The Art of Case Study Research. New York: Free Press.

Straits, K. (2002). Innovation in Singapore Organizations. Singapore: Straits Knowledge.

Sullivan, D. M., \& Marvel, M. R. (2011). Knowledge acquisition, network reliance and early-stage technology venture outcomes. Journal of Management Studies, 48(6), 1169-1193. doi: 10.1111/j.1467-6486.2010.00998.x

Tan, B. S. (2004). The Consequences of Innovation. The Public Sector Innovation Journal, 9(3), 23-39.

Tekes (2007). Seizing the White Space: Innovative Services Concepts in the United States. Technology Review, 205, 15-88.

Thomas, J., \& Nelson, J. (1996). Research Methods in Physical Activity. 3rd ed. USA: Human Kinetics.

UNCTAD. (2011). World Investment Report 2011: Transnational Corporations and the Internationalization of $R \& D$. Geneva: United Nations.

UNIDO. (2011). Industrial Development Report 2005: Capability Building for Catching-up. Historical, Empirical and Policy Dimensions. Vienna: United Nations Industrial Development Organization.

Vargas-Hernandez, J. G., \& Garcia-Santillan, A. (2011). Management in the innovation project, Journal of Knowledge Management. Economics and Information Technology, 7, 148-171.

Varghese, P. G. (2013). A communication-focused model for learning and education. Business Education \& Accreditation, 5(2), 117-130.

Wong, P., \& He, Z. (2013). The Moderating Effect of a Firm's Internal Climate for Innovation on the Impact of Public R\&D Support Programmes. International Journal of Entrepreneurship and Innovation Management, 3, 56-74. 
World Bank. (2011). Knowledge Assessment Methodology. Washington DC: World Bank.

\title{
Authors
}

The contribution share of authors is equal and amounted to $1 / 3$ each of them.

\section{Mantas Vilys}

PhD, Associate Professor at Vilnius Gediminas Technical University. In 2004 he graduated from Vilnius University (VU), the Faculty of Physics, acquired Bachelor's degree in Physics. In 2006 he graduated from Vilnius Gediminas Technical University (VGTU), the Faculty of Business Management, acquired Master's degree in Business Management. In 2007-2011 he was a PhD student of Vilnius Gediminas Technical University and since 2006 he has been delivering lectures at the same university. Research interests: innovation, public innovation support, management.

\section{Artūras Jakubavičius}

PhD, Professor at Department of International Economics and Management, Vilnius Gediminas Technical University. Innovation management expert - consultant at Lithuanian Innovation Centre. More than 20 years he is focusing on innovation management, innovation support systems, innovation financing, innovation networking issues. Since 1994 he has been delivering lectures for students in universities. Research interests: innovation management, innovation support systems, innovation clusters.

\section{Eigirdas Žemaitis}

PhD student, lecturer at Department of International Economics and Management, Creative Industry faculty at Vilnius Gediminas Technical University. Innovation and creativity consultant . 13 years of consultancy and training on innovation management, creativity, marketing. Research interests: technology transfer, innovation management, innovation support systems.

\author{
Correspondence to: \\ Assoc. Prof. Mantas Vilys, PhD \\ Vilnius Gediminas Technical University \\ Business Management Faculty \\ Department of International Economics and Business Management \\ Sauletekio al. 11, LT-10223 Vilnius, Lithuania \\ mantas.vilys@vgtu.lt
}

\section{Copyright and License}

This article is published under the terms of the Creative Commons Attribution - NonCommercial - NoDerivs (CC BY-NC-ND 3.0) License http://creativecommons.org/licenses/by-nc-nd/3.0/ 